\title{
Problems faced by women SHGs members in self-help group in Kanpur Nagar
}

\author{
ANCHAL SHARMA AND REKHA DAYAL
}

Received: 05.11.2015; Revised: 14.11.2015; Accepted: 23.11.2015

See end of the paper for authors' affiliations ANCHAL SHARMA

Department of Family Resource Management, M.A.B. College of Home Science, C.S.A. University of Agriculture and Technology, KANPUR (U.P) INDIA
ABSTRACT : In India self-help groups represent a unique approach to financial intermediation. The concept combines access to low-cost financial services with a process of self-management and development for women who are SHG members. SHGs are seen to confer many benefits, both economic and social. SHGs enable women to grow their savings and to access the credit which banks are increasingly willing to lend. SHGs can also be community platform from which women become active in village affairs, stand for local election or take action to address social or community issues. . Maximum (53.75\%) respondents 'always' faced "lack of economic freedom" constraint while 59.58 per cent respondents faced constraints of "irregular visit by extension worker" whereas, 65.00 per cent respondents faced the problem of "complicated and time-consuming loan procedure". More than fifty-seven per cent respondents 'always' faced the problem of "lack of communication between trainers and political leader".

KEY WORDS: Economic constraint, Political constraint, Mass media exposure, Self-help group

- HOW TO CITE THIS PAPER : Sharma, Anchal and Dayal, Rekha (2015). Problems faced by women SHGs members in self-help group in Kanpur Nagar. Asian J. Home Sci., 10 (2) : 442-448. 